\title{
Ricardo Palma en el análisis literario de Estuardo Núñez
}

Por Jesús Cabel 
Crítico, poeta y antólogo. Doctor en Administración por la Universidad Inca Garcilaso de la Vega. Miembro Correspondiente de la Academia Peruana de la Lengua. 
Desde esa singular y excelente obra La literatura peruana en el siglo $X X$, el maestro Estuardo Núñez, traza con excepcional originalidad el legado del siglo anterior $y$ nos señala fehacientemente la existencia de dos figuras representativas consagradas: las de Ricardo Palma y Manuel González Prada. Es cierto que las tradiciones de Palma fueron publicadas a lo largo de la segunda mitad del siglo XIX y que su escritura cubre un espacio de más de medio siglo. "La capacidad para ser original -afirma Núñez- fue en Palma tan neta y rotunda que hasta en la forma del estilo y ya no solamente en los asuntos, dio la impresión y constituyó la realidad de un nuevo y brillante artífice de las letras. Como si no bastara el hecho de dominar en su obra la brillantez y la novedad de la idea, ni la fina interpretación personal inserta en la urdimbre de la anécdota histórica o seudohistórica, ni el haber logrado la incorporación de las realidades espaciales o temporales, locales o anímicas del país a la literatura, Palma afirma la inconformidad con muchos moldes tradicionales, y señala un nuevo rumbo e imparte una enseñanza seguida por los nuevos escritores" y más adelante concluye: "Doble y excelente condición literaria se encuentra en él: originalidad para captar lo real y originalidad para desenvolver literariamente los temas. Por eso, Palma resulta a la vez, el escritor selecto y el escritor de la multitud. Unía el cuidado de la dicción con la frescura y vitalidad del tema. Realizaba al par que el ideal clásico de don

1 Estuardo Núnez. La literatura peruana en el siglo XX. México: Editorial Pormaca S.A., 1965. p.13. 
Andrés Bello, quien clamaba por la expresión perfecta, el ideal de otro grande y auténtico americano, don Domingo Faustino Sarmiento, escritor rudo de realidades, de sangre y de idea" ${ }^{2}$. Lo cierto es que desde esa fecha plantea que la influencia de éste en América no presenta ningún estudio y destaca que entre los discípulos peruanos estuvieron José Antonio Lavalle, Clorinda Matto de Turner, Celso Torres, Marco A. de la Fuente y Mariano Ambrosio Cateriano, entre otros.

Partiendo de la definición que el propio Palma intentó de las tradiciones, cuando señala que por sus características presenta "estilo ligero, frase redondeada, sobriedad en las descripciones, rapidez en el relato y presentación de personajes y caracteres en un rasgo de pluma, diálogo sencillo a la par que animado, novela en miniatura...", Núñez agregará: "peculiar mezcla de elementos diacrónicos (situados en el tiempo) y sincrónicos (fuera del tiempo), la acción suele situarse en un pasado mediato o inmediato. Especialmente, la acción se desarrolla dentro de un escenario propio del país, o sea en un lugar determinado de Hispanoamérica" ${ }^{3}$ que, sin duda, resulta otorgarle al concepto una amplitud y profundidad magistral, vigente aún para nuevos estudios críticos, como la propuesta de Alberto Escobar cuando precisa que en la tradición "adquiere forma un material nuestro, accede a la literatura 'realizándose', un complejo de vivencias y experiencias que, por primera vez, poseemos plenamente en lengua española. Así en el contraste y juego de pretérito y presente, de 'promesa' y desencanto sociales; de idealidad y desromantización; de piropo, refrán, esgrima verbal e ironía volteriana; de religiosidad y anticlericalismo; (..) perfila Palma el hallazgo de una norma idiomática que consagra en el

2 Ibíd., p. 14.

3 Estuardo Núñez. Ricardo Palma/ Escritor Continental. Lima: Banco Central de Reserva del Perú, 1998. p. X. 
quehacer literario el paradigma de la oralidad. He ahí inclusive, revelada de modo evidente, la asombrosa continuidad de nuestra progresión narrativa. Pero ahora se trata de un tono oral en la prosa, en la entonación del período, en la elección del léxico y en el empleo de locuciones y proverbios"4. Sin embargo, para José Carlos Mariátegui, las tradiciones "tienen política y socialmente, una filiación democrática. Su burla roe risueñamente el prestigio del Virreinato y de la aristocracia"

Discutida y ampliada lo que vendrá a constituirse en tradición, Núñez, magistralmente pasa a estudiar su proyección no solo a nivel nacional sino en el ámbito hispanoamericano. Así el crítico encuentra como punto de partida los estudios someros de Clemente Palma, hijo del eximio escritor, y opta por un análisis más exhaustivo y, por cierto, más justo y necesario. Entonces surge una pregunta natural: ¿desde cuándo empieza la expansión de la tradición bajo el liderazgo de Palma? Para Núñez, el asunto comienza desde la primera serie de sus Tradiciones, en 1872, no sin antes señalar como ilustre antecedente, el destierro que Palma soporta en Chile y sus contactos con intelectuales de Santiago y Valparaíso, entre diciembre de 1860 y octubre de 1862 . No olvidemos que los seguidores de Palma en el país vecino nos dicen que es "tal vez la más numerosa". Su influencia no tiene precedentes en la historia de la literatura peruana e hispanoamericana del siglo que le tocó vivir. Hay que destacar su recia personalidad, la originalidad de sus creaciones, el nuevo y vigoroso planteamiento de su lenguaje, el arraigo de su proyección social y principalmente el encanto y gracia natural de su estilo tan singular como propio. Un buen ejemplo lo constituye el escritor venezolano radicado en el Perú, don Juan Vicente Camacho (1829-1872) a quien Palma,

4 Alberto Escobar. La narración en el Perú. Lima: Librería Editorial Juan Mejía Baca, I ${ }^{\text {a }}$ ed. 1956; 2da. ed. 1960.

5 José Carlos Mariátegui. Siete ensayos de interpretación de la realidad peruana. Lima: Sociedad Editora Amauta, 1928. 
pese a ser de menor edad que aquél, lo orienta y contribuye a estructurar una obra sólida que concluye también en la publicación de relatos que adquieren el apelativo de tradiciones. Otros escritores residentes en el país que afirman este nuevo estilo de narrar son la argentina Juana Manuel Gorriti, el boliviano Julio Lucas Jaimes y el ecuatoriano Nicolás Augusto González.

Núñez cita y recorre con diligencia y profundidad a los críticos que habitan los lugares más distantes y distintos del habla hispana y encuentra efectivamente que existe "unanimidad de criterio" acerca del hecho de que Ricardo Palma no solo es el egregio creador de la especie literaria llamada tradición, sino de su definitiva influencia en sus coetáneos, quienes no vacilaban en llamarlo maestro. Es el caso de José Toribio Medina, historiógrafo chileno, quien afirma: "Generalmente se tiene y con razón, como fundador de este género literario a Ricardo Palma... (...) y ya ha quedado como el maestro que todos sus sucesores se han empeñado en seguir, aunque justo será reconocer sin superarlo en cualquier momento, pues ninguno con tanto brillo de dicción, tal donaire en el cuento y tal variedad en los cuadros que supo pintar, diera las normas para el género literario que cultivara el primero"; o la del crítico argentino Antonio Pagés Larraya, cuando prologa la obra del tradicionista Justo Pastor Obligado, y dice: "Las coloridas evocaciones (de Palma) crearon toda una corriente literaria en Hispanoamérica... Ninguno de los otros cultores del género logró superar al creador de esos relatos, salpicados de un gracejo inimitable y que participaban a la vez de la historia, del esbozo costumbrista y de la indagación psicológica, pero sin asomo de empaque con atractiva llaneza y que, a falta de otro nombre para calificarlos, llamó sencillamente tradiciones"7.

6 José Toribio Medina, prólogo a: Aurelio Díaz Meza. Crónicas de la Conquista. Santiago: Edición del autor, 1925.

7 Antonio Pagés Larraya, prólogo a: Tradiciones argentinas de Justo Pastor Obligado. Buenos Aires: Hachette, 1955. 
Hace bien Núñez en explicitar que la irradiación de esa modalidad literaria, las tradiciones, "no constituyó un fenómeno de imitación sino de coincidencia en captar la aspiración de los autores, en descubrir el gusto popular, en adecuar la literatura a las nuevas inquietudes", y luego concluye categóricamente: "No se trataba pues de imitadores de Palma sino de discípulos, de hombres identificados en el mismo ideal creador, de discípulos que hollaron la misma ruta y bebieron en las mismas fuentes, cada uno en su país y con sus propios medios y posibilidades. Palma había descubierto las vetas explotables, había definido la inquietud 'americanista' que informaba a los narradores en todos los ámbitos hispanoamericanos y los había alentado en una acción común, en un movimiento solidario"

Precisamente el libro Ricardo Palma/ Escritor Continental. Tras las huellas de Palma en Hispanoamérica (1998), del insigne maestro Estuardo Núñez, traza un itinerario que llega a los escritores de países como Argentina, Bolivia, Colombia, Costa Rica, Chile, República Dominicana, Ecuador, Guatemala, Honduras, México, Nicaragua, Panamá, Paraguay, Puerto Rico, Uruguay, El Salvador, Venezuela y Perú, donde puede advertirse que más que "un arte menor" estamos frente a un fenómeno literario que sobrepasó la moda para dejarnos una clara lección de perfección del arte de narrar y de avizorar el surgimiento de una literatura propiamente hispanoamericana.

8 Estuardo Núñez, Ibíd., p. XXXI. 